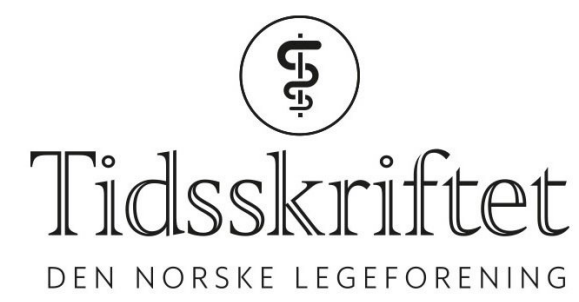

\title{
Forventninger til vår neste helseminister
}

DEBATT

\section{CHRISTER MJÅSET}

E-post: christer.mjaset@legeforeningen.no Christer Mjåset er visepresident i Legeforeningen og leder i Yngre legers forening. Forfatter har fylt ut ICMJE-skjemaet og oppgir ingen interessekonflikter.

Helse-Norge står ved flere veiskiller de kommende årene. Derfor trenger vi en regjering og en helseminister som tør ta grep for å sikre kvaliteten på vår offentlige helsetjeneste. Og som tør prate mer om arbeidsforholdene til de som jobber der.

Under åpningen av Legeforeningens landsstyremøte i mai ble det vist en videohilsen fra helseminister Bent Høie, der han oppfordret til at vi sammen må jobbe for å skape "pasientens helsetjeneste». Det er en selvfølge at pasientene settes først når prioriteringer innen helse skal gjøres. Høie kunne valgt å rette oppmerksomheten mot to andre viktige temaer når han først snakket til norske leger: valg av styringsmodell i helsetjenesten og, ikke minst, helsearbeidernes helsetjeneste.

\section{Foretaksmodellen bør avvikles}

Landsstyret var i vår samstemt om at helseforetaksreformen, som ble innført i 2002, ikke har ført til ønskede resultater. Det ble derfor vedtatt at Legeforeningen vil jobbe for å avvikle reformen. Helse- og omsorgsdepartementet har i prinsippet satt bort driften av sykehusene til en profesjonalisert ledelse, som med en New Public Management-ideologi i ryggen styrer etter økonomiske måltall fremfor å støtte seg på gode faglige råd. Fagarbeiderne - deriblant legene - opplever å miste styring over egen arbeidshverdag og over pasientbehandlingen. Produktiviteten til legene faller (1), og legene bruker mindre tid med pasientene (2). Nesten halvparten av enhetene i norske sykehus rapporterer om dårlig pasientsikkerhetsklima (3). Bare i Helse Sør- $\emptyset$ st har vi det siste halvåret hatt en IKT-skandale og en ventelisteskandale. Og i Spekter-sykehusene har vi hatt tidenes lengste streik, som munnet ut i en erklært «tillitskrise», og nå følges av en arbeidsrettssak.

Likevel vegrer både Høyre og Arbeiderpartiet seg for å rokke ved den eksisterende styringsmodellen. Spesielt er det skuffende at helseministeren har gått tilbake på løftet om å fjerne de regionale helseforetakene. Vi trenger en mindre toppstyrt organisering med kortere lederlinjer og færre ledernivåer. Fagpersonene i helsetjenesten må få mer innflytelse. Det er de som best kjenner pasientenes behov. 


\section{Helsearbeidernes helsetjeneste}

Det er godt dokumentert at arbeidsmiljø og arbeidsforhold kan påvirke pasientsikkerheten (4). Når helseministeren henvender seg til de som jobber med pasientene, bør han snakke mer om helsearbeidernes helsetjeneste. De siste årene har samtlige profesjoner i helsetjenesten merket presset om å «jobbe smartere» og mer effektivt. Mange føler allerede at strikken er tøyd godt og lenge og står i fare for å ryke. Fjorårets konflikt i Spektersykehusene er et godt eksempel på det.

Arbeidsgiversiden $\emptyset$ nsker $\emptyset \mathrm{kt}$ fleksibilitet i legenes arbeidstid, langt utover arbeidsmiljølovens grenser. Dialog og samarbeid erstattes av overstyring og diktat. Det kollektive vernet, som lenge har vært en selvfølge i norsk næringsliv, fremstilles som en bremsekloss for å kunne drive enda mer kostnadseffektivt, selv om det går på forsvarligheten løs. I en slik argumentasjonsrekke hoppes det bukk over at norske sykehusleger jobber nesten 1 ooo årsverk gratis i overtid (5). Dugnadsånden kan fort forsvinne om de ansatte ribbes for kontroll over egen arbeidstid. Det er påkrevd at den neste helseministeren har en formening om hvordan arbeidsgiverpolitikken i sykehus skal være.

Det er et paradoks at politikerne har latt arbeidsgiversiden i statlige eide virksomheter få ture frem slik de har gjort, flere ganger på tvers av politiske ønsker. Faste stillinger ble for eksempel vedtatt av helseministeren i 2010. Etter syv år er andelen faste stillinger ved Oslo universitetssykehus bare i overkant av 10\% (6). Ansvaret ligger hos politikerne.

\section{Politisk handling for fastlegeordningen}

Også når det kommer til fastlegeordningen, har jeg hørt mangt et unnvikende politikersvar når allmennleger trekker frem utfordringer om et stadig økende arbeidspress og ber om insentiver for å kunne ha kortere pasientlister. Den nåværende ministerens løsning har vært å innføre tverrfaglige primærhelseteam. Det kan være til hjelp for pasienter med sammensatte lidelser, men mitt inntrykk er pasientene først og fremst ønsker seg mer tid med egen lege. Flere IT-gründere har skjønt at dette er et marked å tjene penger i. Det siste halvåret har det dukket opp apptjenester med tilbud om alt fra hjemmebesøk til videokonsultasjoner med leger organisert i egne vakttjenester. Etterspørselen er der, og tilbudet kommer mest sannsynligvis bare til å øke. Det applegene imidlertid ikke kan tilby, er kontinuitet og kjennskap til pasientenes sykdomshistorie. For å tilby det må finansieringsordningen til fastlegene reevalueres slik at listelengdene blir håndterlige og tiden med pasienten blir opprioritert.

\section{Ta vare på de ansatte}

«Da streiken var over, skulle jeg ønske at jeg hadde en annen arbeidsgiver å gå til», sa en ung, kvinnelig turnuslege til meg. Hun så ingen fremtid i et system der ledelsen har full styring over arbeidstiden hennes. Det er sørgelig om legene søker seg bort fra det offentlige av slike grunner. Det kan fort føre til mer privatisering i helsesektoren. Jeg ønsker meg en offentlig helsetjeneste som tar var vare på sine ansatte. Men da må helseministeren forstå at man ikke kan lage en pasientens helsetjeneste uten helsearbeidere.

\section{LITTERATUR:}

1. Johannessen KA, Kittelsen SA, Hagen TP. Assessing physician productivity following Norwegian hospital reform: A panel and data envelopment analysis. Soc Sci Med 2017; 175: 117 - 26. [PubMed][CrossRef]

2. Rosta J, Aasland OG. Legers arbeidstid og tid til pasientarbeid i perioden 1994-2014. Tidsskr Nor Legeforen 2016; 136: 1355 - 9. [PubMed][CrossRef]

3. Nye nasjonale tall om pasientsikkerhet. Helsedirektoratet, 2016. 
www.pasientsikkerhetsprogrammet.no/aktuelt/nyheter/nye-nasjonale-tall-om-pasientsikkerhet (9.2.2016).

4. Personellets trivsel kan påvirke pasientsikkerheten. Kunnskapssenteret 8.9.2016. www.kunnskapssenteret.no/nyheter/personellets-trivsel-kan-pavirke-pasientsikkerheten (13.9.2016).

5. Haugli Å. Leger sier de jobber 924 årsverk gratis. Dagens Næringsliv 18.5.2016.

6. Haugli Å. Oslo universitetssykehus mangler oversikt over legene. Dagens næringsliv 22.5.2017.

Publisert: 4. september 2017. Tidsskr Nor Legeforen. DOI: 10.4045/tidsskr.17.0654

Mottatt 1.8.2017, godkjent 7.8.2017.

(C) Tidsskrift for Den norske legeforening 2020. Lastet ned fra tidsskriftet.no 